\title{
Microwave Ablation of Symptomatic Benign Thyroid Nodules: Energy Requirement per ml Volume Reduction
}

\section{Mikrowellenablation von symptomatischen, benignen Schild- drüsenknoten: Energiebedarf pro ml Volumenreduktion}

Authors

Affiliations
Y. Korkusuz ${ }^{1}$, K. Kohlhase' ${ }^{1}$, D. Gröner ${ }^{1}$, C. Erbelding' ${ }^{1}$, W. Luboldt ${ }^{2}$, C. Happel $^{3}$, S. Ahmad ${ }^{4}$, T. J. Vogl ${ }^{5}$, F. Gruenwald ${ }^{3}$

Affiliation addresses are listed at the end of the article.
Key words

- head/neck

- thyroid

- ablation procedures

- interventional procedures

received $\quad 21.4 .2016$ accepted $\quad 29.7 .2016$

\section{Bibliography}

DOI http://dx.doi.org/

10.1055/s-0042-115416

Published online: 14.9.2016

Fortschr Röntgenstr 2016; 188

1054-1060 @ Georg Thieme

Verlag KG Stuttgart · New York .

ISSN 1438-9029

\section{Correspondence}

Konstantin Kohlhase

Department of Nuclear

Medicine, University Hospital

Frankfurt

Theodor-Stern-Kai 7

60590 Frankfurt

Germany

Tel.: ++ 49/69/63016783

konstantin_k@hotmail.de

\section{Zusammenfassung}

\section{$\nabla$}

Hintergrund: Mikrowellenablationen (MWA) stellen eine neuartige thermoablative Behandlung für benigne Schilddrüsenknoten dar. Ziel war es, die benötigte Energie pro ml Volumenreduktion zu benutzen, um die benötigte Energie für ein volume-of-interest (VOI) abschätzen zu können. Methode: 25 Patienten mit 25 Knoten (6 solide, 13 komplex und 6 zystisch) wurden durch MWA behandelt. Die übertragene Energie (E) wurde mit der Volumenveränderung $(\Delta \mathrm{V})$ nach 3 Monaten korreliert. Der Energiebedarf pro ml Volumenreduktion wurde durch $\mathrm{E} / \Delta \mathrm{V}$ bestimmt.

Ergebnisse: MWA zeigte eine signifikante $(\mathrm{p}<0,0001)$ Volumenreduktion $(\Delta \mathrm{V})$ im Mittel von $12,4 \pm 13,0 \mathrm{ml}$ (range: $1,5-63,2 \mathrm{ml}$ ) und eine relative Reduktion von $52 \pm 16 \%$ (range: 22 $77 \%)$. Es zeigte sich eine positive Korrelation zwischen $\mathrm{E}$ und $\Delta \mathrm{V}(\mathrm{r}=0,82 ; \mathrm{p}<0,05)$. Die mittlere $\mathrm{E} / \Delta \mathrm{V}$ war $1,52 \pm 1,08$ (range: $0,4-4,6$ ) $\mathrm{kJ} / \mathrm{ml}$ für alle Knoten und 2,30 $\pm 1,5(0,9-4,6) ; 1,5 \pm 0,9$ $(0,4-3,6) ; 0,75 \pm 0,25(0,4-1,2) \mathrm{kJ} / \mathrm{ml}$ für solide, komplexe und zystische Knoten mit einer signifikanten Differenz der in $\mathrm{E} / \Delta \mathrm{V}$ zwischen soliden und zystischen Knoten ( $p<0,03$ ).

Schlussfolgerung: Die benötigte Energie pro Volumen ist abhängig von der Knotenkomposition. Solide Knoten benötigen mehr Energie als zystische. Die abgeschätzte Energie für ein volume-of-interest sollte als zusätzlicher Parameter helfen, eine Über- oder Unterbehandlungen zu vermeiden.

Kernaussagen:

> Die abgeschätzte benötigte Energie für ein Volume-of-interest ist abhängig von der Knotenmorphologie.

- In soliden Knoten ist eine höhere Energie-Transmission empfohlen als bei zystischen Knoten.

> Die Energietransmission als zusätzlicher Parameter neben dem Ultraschall ist nützlich, die periprozedurale Überwachung zu verbessern.

\section{Abstract \\ $\nabla$}

Purpose: Microwave ablation (MWA) represents a novel thermal ablative treatment of benign thyroid nodules. The aim was to determine the energy required per ml volume reduction in order to match the required energy to the volume-of-interest (VOI).

Materials and Methods: 25 patients with 25 nodules ( 6 solid, 13 complex and 6 cystic) were treated by microwave ablation (MWA). The transmitted energy (E) was correlated with the volume change $(\Delta \mathrm{V})$ after 3 months. The energy required per $\mathrm{ml}$ volume reduction after 3 months was calculated by $\mathrm{E} / \Delta \mathrm{V}$.

Results: MWA resulted in a significant $(\mathrm{p}<0.0001)$ volume reduction $(\Delta \mathrm{V})$ with a mean of 12.4 $\pm 13.0 \mathrm{ml}$ (range: $1.5-63.2 \mathrm{ml}$ ) and relative reduction of $52 \pm 16 \%$ (range: $22-77 \%$ ). There was a positive correlation between $\mathrm{E}$ and $\Delta \mathrm{V}(\mathrm{r}=0.82$; $\mathrm{p}<0.05$ ). The mean $\mathrm{E} / \Delta \mathrm{V}$ was $1.52 \pm 1.08$ (range: $0.4-4.6) \mathrm{kJ} / \mathrm{ml}$ for all nodules and $2.30 \pm 1.5$ (0.94.6), $1.5 \pm 0.9$ (0.4-3.6), $0.75 \pm 0.25(0.4-1.2) \mathrm{kJ} /$ $\mathrm{ml}$, respectively, for solid, complex and cystic nodules with a significant difference in $\mathrm{E} / \Delta \mathrm{V}$ for solid and cystic $(\mathrm{p}<0.03)$.

Conclusion: The energy required per volume depends on the nodule consistency. Solid nodules require more energy than cystic ones. The estimation of the energy needed per volume-of-interest as an additional parameter should help to avoid under- or overtreatment.

Key Points:

- The estimated required energy for a volumeof-interest depends on the nodule consistency

- In solid nodules a higher energy transmission than in cystic nodules is recommended

- The energy transmission as an additional marker to ultrasound is helpful for improving periprocedural monitoring 
Citation Format:

Korkusuz Y, Kohlhase K, Gröner D et al. Microwave Ablation of Symptomatic Benign Thyroid Nodules: Energy Requirement per ml Volume Reduction. Fortschr Röntgenstr 2016; 188 : 1054-1060

\section{Introduction}

Thermal ablative procedures like laser and radiofrequency ablation are already approved as new reasonable possibilities to treat symptomatic benign thyroid nodules [1 - 3], with radiofrequency ablation (RFA) representing the most common and best evaluated thermal procedure. Minimally invasive thermal ablation has been used in an attempt to prevent the drawbacks of conventional surgery, including large scars, difficulties in reoperation, iatrogenic hypoparathyroidism and general anesthesia. Although minimally invasive surgery has been developed as an alternative to conventional surgery and has shown advantages especially with respect to cosmetic score, it is still limited to a nodule size between $30-40 \mathrm{~mm}$ [4-6]. In contrast to surgery, thermal ablation is performed on an outpatient basis and only under local anesthesia. Sufficient ablation of large nodules $(>40 \mathrm{~mm})$ is also possible, because MWA permeates tissues that are even desiccated or evaporated. This differs from comparable thermal procedures like RFA, which is dependent on local resistance [7, 8]. As microwave ablation (MWA) generates heat by creating a homogeneous electromagnetic field that interacts with water dipoles [7] and creates homogeneous lesions, it is reported to be a safe and effective treatment of benign nodules [9]. Nonetheless, adequate monitoring during ablation is mandatory and is primarily performed using ultrasound $[10,11]$. However, it is not possible to predict the approximate volume reduction right after ablation only on the basis of ultrasound imaging [10]. As the transmitted energy determines the generated heat and therefore influences the ablation itself, it has to be taken into account [8]. Until now, no calibration curve has been established to determine how much energy is necessary to destroy a given volume. Therefore, an energy-versus-efficacy calibration curve is desirable in order to match the required energy to the volume-of-interest (VOI) and avoid under- or overtreatment.

The purpose of the study was to establish an energy versus volume reduction calibration curve in order to better predict the microwave energy needed for a target volume-of-interest (VOI).

\section{Materials and methods}

\section{$\nabla$}

The retrospective study was approved by the ethics committee and written informed consent was obtained from all patients.

\section{Patients}

25 patients (mean age: $54 \pm 13$ years; 12 males, 13 females) with 25 nodules (mean initial volume: $25.2 \mathrm{ml} \pm 24.3 \mathrm{ml}$ [range: 2.6 $100 \mathrm{ml}$ ]; composition: 6 solid, 13 complex and 6 cystic) underwent microwave ablation on an outpatient basis. The inclusion criteria were symptoms requiring surgery (cosmetic problems; compressive symptoms like foreign body sensation, hoarseness and dysphagia) in patients who had refused radioiodine therapy or surgery or had contraindications to surgery. The exclusion criteria included excessive thyroid volume with retrosternal growth, critical adjacency to structures such as vessels, trachea, esophagus and nerves, limited ultrasound visualization ("macro-calcification" and no presentable capsule border) as well as malignancy.

The assessment before ablation included ultrasound imaging using B-mode, color Doppler sonography and elastography. All patients underwent ${ }^{99 \mathrm{~m} T c-p e r t e c h n e t a t e}$ scintigraphy. In the case of "cold" nodules, 99 mTc-MIBI scintigraphy and fine-needle aspiration biopsy were performed to exclude signs of malignancy $[12,13]$.

\section{Microwave ablation - summary of technique}

A generator with a maximum output of $36 \mathrm{~W}$ at a frequency of $928 \mathrm{MHz}$ was used (MedWaves Avecure ${ }^{\mathrm{TM}}$ Microwave Generator; San Diego, California) with an uncooled 14-16 gauge electrode. Prior to the procedure, a short infusion of $0.9 \% \mathrm{NaCl}$ with $2 \mathrm{mg} \mathrm{Me}$ tamizole (Novaminsulfon-ratiopharm, Ulm, Germany) was administered. Under ultrasound guidance local anesthetic (mepivacaine hydrochloride $1 \%$ (AstraZeneca, Wedel, Germany) was injected to reduce the pain during the skin incision and insertion of the electrode. When local anesthesia of the skin was achieved, a 2-mm incision was made to place the MW electrode into the nodule using a transisthmic approach [11]. This approach enables optimal visualization of the electrode as well as ensures the maximum safety margin with respect to vulnerable structures like the carotid arteries, jugular veins, nervus vagus and the recurrent laryngeal nerve, which is situated in the so-called "danger triangle" between the trachea and thyroid [11]. When a transisthmic approach was not possible, a cranio-caudal approach was chosen. The needle was positioned in the nodule under ultrasound guidance. In the case of cystic parts, the fluid was aspirated before MWA was performed [14]. Once the correct position was confirmed, microwave ablation was initiated using the predefined parameters such as power and target temperature. Treatment was started using a footswitch and monitored by ultrasound until the targeted area showed a decrease in echogenicity and/or hyperechogenic microbubbles to indicate vaporization [15] ( $\bullet$ Fig. 1). During this process ablation was fixed in one section, starting with the deepest part of the nodule. Ablation was performed either for 5 minutes, independent of the nodule composition, or until the safety margin was reached. Once ablation was completed, the probe was repositioned and another ablation procedure was performed, thus creating multiple overlapping ablation areas. This procedure, i. e., the multiple-shot technique, was repeated until the whole nodule was hollowed out or the safety margin was reached. The transmitted energy [kJ] was documented.

\section{Measurements}

The volume of the nodules was determined before and 3 months after treatment using ultrasound (SonixTOUCH, Ultrasonix Medical Corporation. Richmond. BC. Canada). The nodule volume and reduction rate were calculated using the following formula for ellipsoid bodies: $\mathrm{V}=\left(\pi^{*} \mathrm{a}^{*} \mathrm{~b}^{*} \mathrm{c}\right) / 6(\mathrm{~V}=$ volume; $\mathrm{a}=$ largest diameter; $\mathrm{b}, \mathrm{c}=$ perpendicular diameters). The nodules were categorized according to their consistency: primary solid (solid tissue $>80 \%$ ), cystic (solid tissue $<20 \%$ ) or mixed subgroups (complex). 


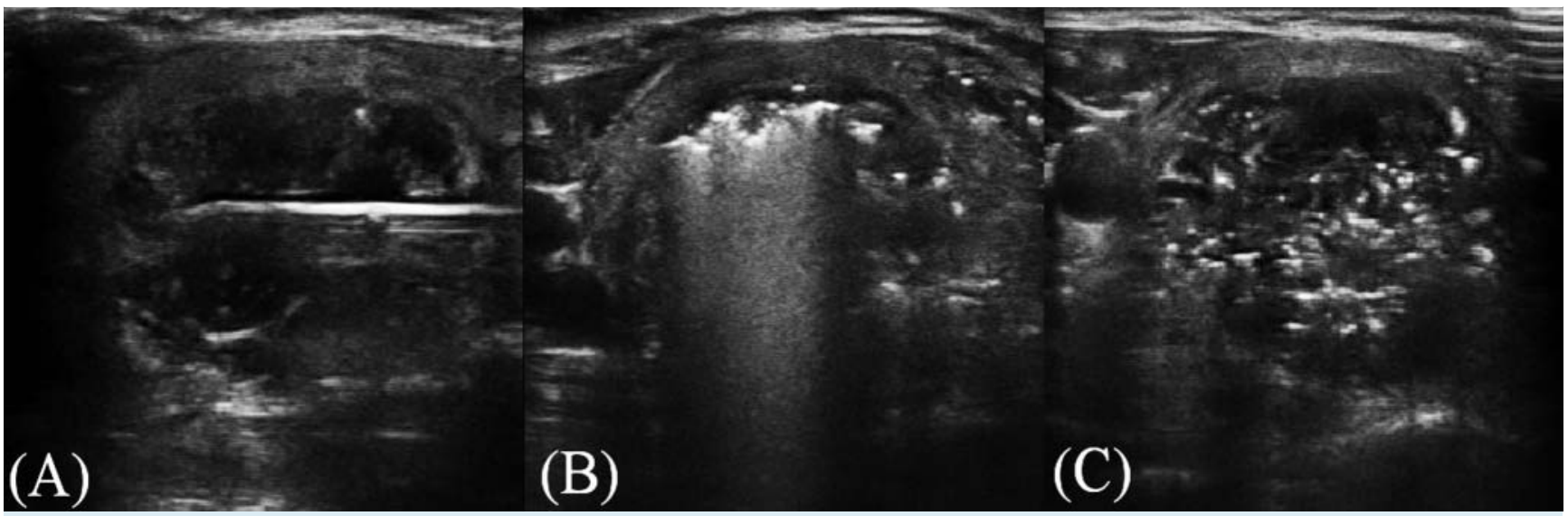

Fig. 1 Sonographic guidance of microwave ablation of a complex nodule with solid and cystic parts. A The probe is visualized before ablation to ensure, that the active tip is completely placed within the targeted area. B During ablation the heat is visualised by hyperechogenic "microbubbles" which are homogeneously distributed in the cystic regions. C Consecutive sonographic control after ablation shows hyperechogenic lesions within the ablated area.
Abb. 1 Sonografische Überwachung einer Mikrowellenablation eines komplexen Knotens mit soliden und zystischen Anteilen. A Die Sonde wird vor der Ablation sonografisch kontrolliert, wobei darauf geachtet wird, dass die active tip komplett in dem gewünschten Bereich liegt. B Während der Ablation ist die Wärmeentwicklung durch hyperechogene „microbubbles“ darstellbar, die besonders in zystischen Regionen homogen verteilt sind, $\mathbf{C}$ Die anschließende sonografische Kontrolle nach der Ablation zeigt hyperechogene Läsionen im Bereich der Ablationszone.

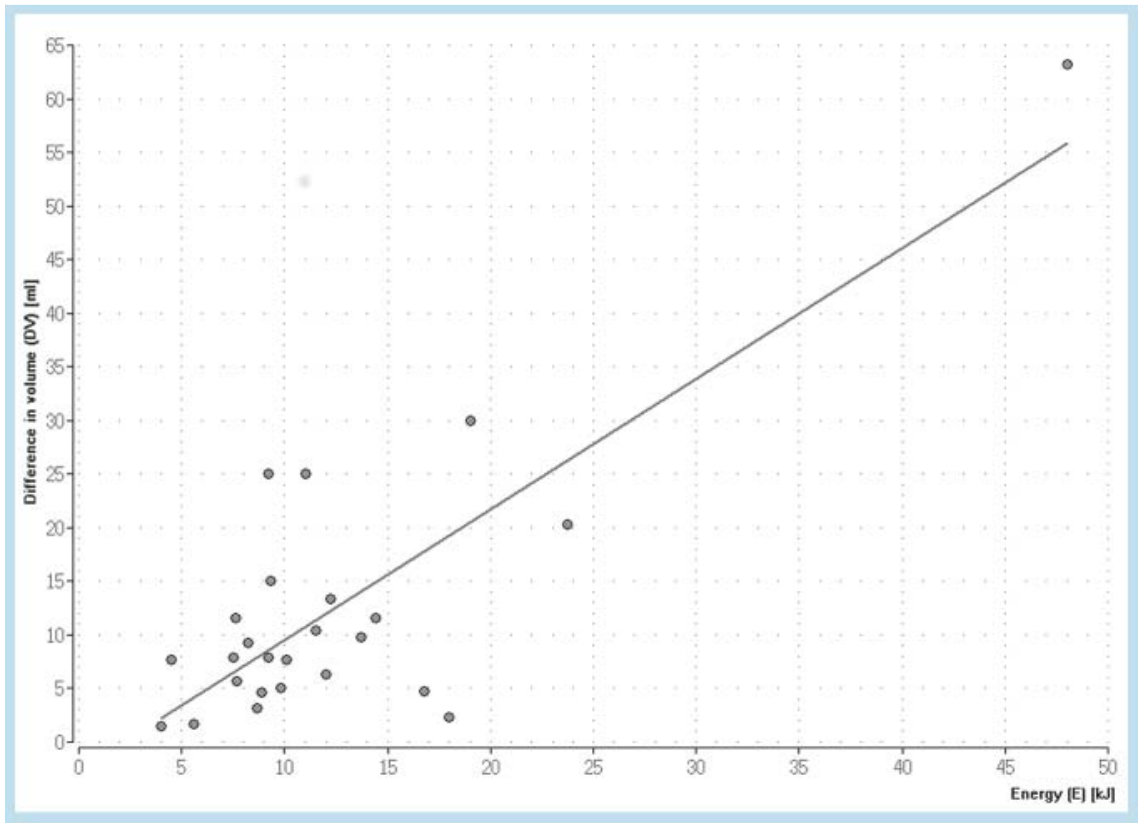

Fig. 2 Correlation between applied energy $(E)$ and resulting difference in volume $(\Delta \mathrm{V})$ observed 3 months after microwave ablation (Pearson correlation coefficient $r=0.82$ ).

Abb. 2 Korrelation zwischen der applizierten Energie (E) und der resultierenden Volumendifferenz $(\Delta \mathrm{V}) 3$ Monate nach der Mikrowellenablation (Pearson correlation coefficient $r=0,82$ ).

\section{Statistical analysis}

Statistical analysis was performed with BiAS, version 10.04 (epsilon Verlag, 1989 - 2013, Frankfurt, Germany). The Wilcoxon matched pairs test was used to evaluate the significance in the volume change $(\Delta \mathrm{V})$. The Kruskal-Wallis test corrected by Bonferroni was used to evaluate the significance of differences under subgroups regarding the energy required per volume change $(E / \Delta V)$. The Pearson correlation coefficient was used to evaluate the correlation between the energy $(E)$ and volume change $(\Delta V)$. Statistical significance was indicated with $\mathrm{p}$-values $<0.05$.

\section{Results}

$\nabla$

MWA resulted in a significant $(\mathrm{p}<0.0001)$ volume reduction $(\Delta \mathrm{V})$ after 3 months with a mean of $12.4 \pm 13.0 \mathrm{ml}$ (range: $1.5-63.2 \mathrm{ml}$ ) corresponding to a relative reduction of $52 \pm 16 \%$ (range: $22-77 \%$ ) ( $\diamond$ Table 1, e.g. $\bullet$ Fig. 3). There was a positive correlation between $\mathrm{E}$ and $\Delta \mathrm{V}$ (Pearson correlation coefficient $\mathrm{r}=0.82$ for all nodules (ه Fig. 2). The mean $\mathrm{E} / \Delta \mathrm{V}$ was $1.52 \pm 1.08$ (range: $0.4-7.65$ ) $\mathrm{kJ} / \mathrm{ml}$ for all nodules and $2.30 \pm 1.50(0.9-4.60), 1.5 \pm 0.9(0.4-3.6)$, $0.75 \pm 0.25(0.4-1.2) \mathrm{kJ} / \mathrm{ml}$, respectively, for solid, complex and cystic nodules ( $\bullet$ Table 1$)(\mathrm{p}<0.03)$. 
Table 1 Analysis of microwave ablation in benign thyroid nodules in relation to the applied energy ( $E$ ).

Tab. 1 Analyse der Mikrowellenablation benigner Schilddrüsenknoten in Relation zur applizierten Energie (E).

\begin{tabular}{|c|c|c|c|c|c|c|}
\hline $\mathbf{N}^{\circ}$ & $\mathrm{V}_{\mathrm{o}}[\mathrm{ml}]$ & $\mathrm{V}_{\text {three month }}[\mathrm{ml}]$ & $\Delta \mathrm{V}[\mathrm{ml}]$ & $\begin{array}{l}\text { applied energy (E) } \\
{[\mathrm{kJ]}}\end{array}$ & $\begin{array}{l}\text { energy per } \Delta V \\
E / \Delta V \\
{[\mathrm{~kJ} / \mathrm{ml}]}\end{array}$ & type \\
\hline 1 & 3.45 & 1.1 & 2.35 & 10.8 & 4.6 & \multirow{6}{*}{ solid } \\
\hline 2 & 7.2 & 4.0 & 3.2 & 8.6 & 2.7 & \\
\hline 3 & 5.4 & 3.7 & 1.7 & 5.6 & 3.3 & \\
\hline 4 & 10.4 & 2.5 & 7.9 & 7.5 & 0.9 & \\
\hline 5 & 25.7 & 20.0 & 5.7 & 7.7 & 1.4 & \\
\hline 6 & 33.5 & 20.2 & 13.4 & 12.2 & 0.9 & \\
\hline 1 & 18.8 & 9 & 9.8 & 13.7 & 1.4 & \multirow{13}{*}{ complex } \\
\hline 2 & 15 & 3.4 & 11.6 & 14.4 & 1.2 & \\
\hline 3 & 20.7 & 10.28 & 10.4 & 11.5 & 1.1 & \\
\hline 4 & 28.7 & 8.43 & 20.3 & 23.8 & 1.2 & \\
\hline 5 & 7.1 & 2.4 & 4.7 & 16.8 & 3.6 & \\
\hline 6 & 19.3 & 11.6 & 7.7 & 10.1 & 1.3 & \\
\hline 7 & 46 & 21 & 25.0 & 9.2 & 0.4 & \\
\hline 8 & 20.3 & 8.7 & 11.6 & 7.6 & 0.7 & \\
\hline 9 & 2.6 & 1.1 & 1.5 & 4 & 2.7 & \\
\hline 10 & 16.6 & 8.9 & 7.7 & 4.5 & 0.6 & \\
\hline 11 & 7.2 & 2.6 & 4.6 & 8.9 & 1.9 & \\
\hline 12 & 15 & 10 & 5.0 & 9.8 & 2.0 & \\
\hline 13 & 14.9 & 8.6 & 6.3 & 12 & 1.9 & \\
\hline 1 & 85 & 21.79 & 63.2 & 48 & 0.8 & \multirow{6}{*}{ cystic } \\
\hline 2 & 14.3 & 6.4 & 7.9 & 9.2 & 1.2 & \\
\hline 3 & 14.8 & 5.5 & 9.3 & 8.2 & 0.9 & \\
\hline 4 & 43 & 28 & 15.0 & 9.3 & 0.62 & \\
\hline 5 & 55 & 30 & 25.0 & 11 & 0.4 & \\
\hline 6 & 100 & 70 & 30.0 & 19 & 0.6 & \\
\hline \multirow{2}{*}{$n=25$} & $25.2 \pm 24.3$ & $12.8 \pm 14.6$ & $12.4 \pm 13.0$ & $12.13 \pm 8.67$ & $1.52 \pm 1.08$ & mean $\pm S D$ \\
\hline & $2.6-100.0$ & $1.1-70.0$ & $1.5-63.2$ & $4.0-48.0$ & $0.4-4.6$ & range \\
\hline
\end{tabular}

\section{Discussion}

This study shows that MWA is an effective method for reducing the volume of benign thyroid nodules (e.g. $\odot$ Fig. 3). Our results are in accordance with Yue et al. [9] who reported a mean volume reduction of $41 \%$ after 3 months and $65 \%$ after 6 months. The long timescale of MWA's effects make prediction of treatment outcomes difficult. Therefore, an energy-versus-efficacy calibration curve seems to be beneficial in order to improve therapeutic handling and better match the expected volume reduction. This is especially necessary for MWA because it generates higher temperatures at a faster rate than comparable thermoablative methods such as RFA. Its energy output is relatively high in the confined space of the thyroid, which results in less controllability and predictability $[16,17]$. Since an effect on surrounding nerves and vessels can't be excluded, the procedure has to be guided carefully [18]. Currently, guidance is primarily performed using conventional B-mode sonography with high-resolution transducers, which especially improves guidance with respect to superficial structures and facilitates the maintenance of a safety distance. Further imaging techniques, such as elastography and contrast-enhanced ultrasound (CEUS), are described, although these techniques are reported to be best suited for periprocedural guidance. Elastography as well as CEUS improve the differentiation between benign and malignant nodules, whereas only elastography is currently recommended for the thyroid in the EFSUMB guidelines [19-23]. Recent studies also indicated positive effects of real-time elastography on the guidance of thermal abla- tion and showed an improved delineation of the ablated area compared to B-mode sonography $[24,25]$. As the study was performed in the liver, future studies should involve an evaluation of thyroid ablation to determine its clinical relevance. Nevertheless, elastography is highly dependent on the experience of the examiner, thus the transferability of these results is limited. In contrast, CEUS is not reliable for monitoring during thermal ablation, because MWA creates so-called microbubbles [14], which interfere with CEUS imaging. After ablation, CEUS is reported to predict successful treatment of soft tissue and is used to identify local recurrences of malignant neoplasia $[21,26]$. In particular, the imaging of malignant lesions benefits from CEUS as success depends on exact ablation. An additional benefit to standard ultrasound imaging of benign thyroid nodules has not been evaluated. The positive correlation $(r=0.82)$ between the applied energy and volume reduction enables an approximate prediction of volume reduction during ablation and should therefore improve periprocedural guidance in addition to standard ultrasound.

Our study shows a good correlation between energy and volume $(\mathrm{r}=0.82)(\bullet$ Fig. 2) to estimate the required energy per ablative VOI using: $\mathrm{E} / \Delta \mathrm{V} \times \mathrm{VOI}$ with $2.30 \pm 1.50$ (0.9-4.6), $1.5 \pm 0.9$ (0.43.6), $0.75 \pm 0.25(0.4-1.2) \mathrm{kJ} / \mathrm{ml}$, respectively, for solid, complex and cystic nodules.

Furthermore, our study shows that solid nodules require significantly more energy than cystic nodules ( $2.30 \mathrm{vs} .0 .75 \mathrm{~kJ} / \mathrm{ml}$ ). This finding indicates that the consistency of the thyroid nodule must be taken into account when estimating the energy requirement. The fact that solid nodules require more energy than cystic ones 


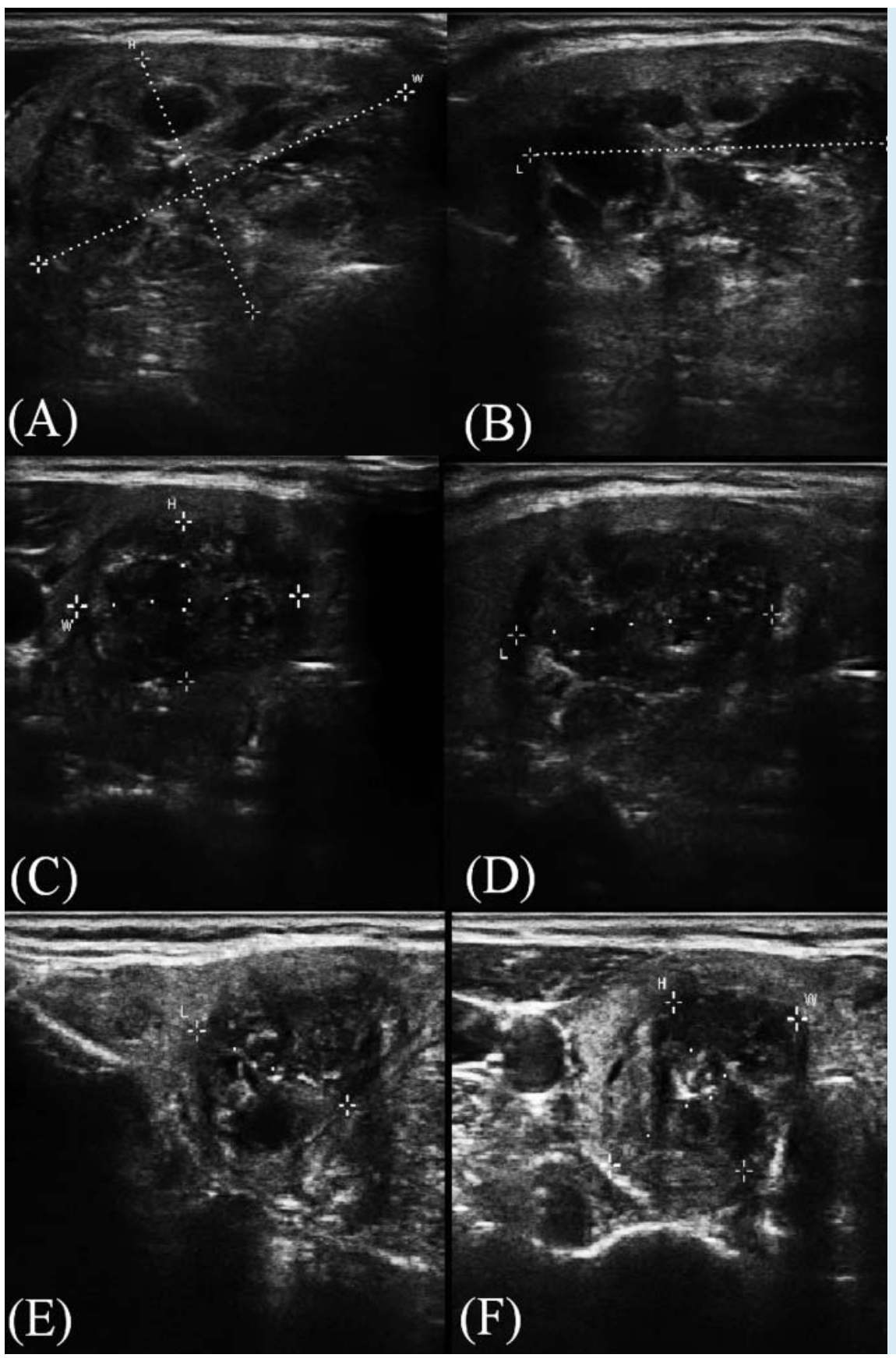

Fig. 3 Measurement of the nodule volume before ablation (A + B: Length (L): $40.85 \mathrm{~mm}$; Heigh (H)t: $31.63 \mathrm{~mm}$; Width (W): $46.41 \mathrm{~mm}$; V: $28.72 \mathrm{~cm}^{3}$ ), 3 months after ablation (C + D: L: $33.11 \mathrm{~mm}$; H: $18.06 \mathrm{~mm}$; W: $29.44 \mathrm{~mm}$; V: $\left.8.43 \mathrm{~cm}^{3}\right)$ and 12 months after ablation (E + F: L: $21.08 \mathrm{~mm} ; \mathrm{H}$ : $19.77 \mathrm{~mm}$; W: $28.82 \mathrm{~mm}$; V: $5.75 \mathrm{~cm}^{3}$ ).

Abb.3 Messung des Knotenvolumens vor der Ablation (A + B: Länge (L): 40,85 mm; Höhe (H)t: $31,63 \mathrm{~mm}$; Breite (W): $\left.46,41 \mathrm{~mm} ; \mathrm{V}: 28,72 \mathrm{~cm}^{3}\right)$, 3 Monate nach Ablation (C + D: L: 33,11 mm; H: $18,06 \mathrm{~mm}$; W: $29,44 \mathrm{~mm}$; V: $8,43 \mathrm{~cm}^{3}$ ) und $12 \mathrm{Mo}$ nate nach Ablation ( $\mathbf{E}+\mathbf{F}: \mathrm{L}: 21,08 \mathrm{~mm} ; \mathrm{H}: 19,77 \mathrm{~mm}$; $\left.W: 28,82 \mathrm{~mm} ; \mathrm{V}: 5,75 \mathrm{~cm}^{3}\right)$.

can be explained by the higher water content, which increases the conversion of electromagnetic energy into heat [8]. The distribution of microbubbles in the fluid areas of the complex nodule in $\bullet$ Fig. 1 demonstrates the increasing temperature of these areas, which is more homogeneously distributed than in solid areas ( $\bullet$ Fig. 1 ). The homogeneous distribution of water results in homogeneous production of heat leading to homogeneous thermal ablation [14]. Furthermore, in cystic nodules there is no blood flow that carries the heat away (conduction) which further increases the efficiency of MWA in cystic nodules. The conduction of heat - the so called "heat-sink effect" $[27,28]$ - decreases the efficiency of thermal ablation, although microwave ablation seems to be less affected than other thermal ablation techniques [28-30]. Nevertheless, current research shows that the pattern of temperature increase during MWA depends on the distance between the probe and the blood vessel as well as on the flow rate inside the vessel, as shown in the liver [31]. Heat loss was reported to be negligible only when the distance to a vessel exceeds $20 \mathrm{~mm}$. However, these results are not fully transferable to the thyroid as the hepatic vessels are significantly larger than those in the thyroid and the negative inferring effect of blood flow on microwave ablation has not been completely investigated yet. In addition to the greater heat conductivity, this phenomenon may explain why solid nodules require more energy for ablation than cystic nodules. Besides consistency, another predictor of the effectiveness of MWA could be the microwave frequency. Lower frequencies have a larger penetration depth and a slower heating rate [8]. Thus, $915 \mathrm{MHz}$ MWA results in damage with a more long-ellipsoid shape, while $2.45 \mathrm{GHz}$ MWA caused damage with a more spherical shape. Therefore, $915 \mathrm{MHz}$ should be used for ellipsoid nodules while $2.45 \mathrm{GHz}$ should be used for spherical ones [16, 32]. 
Non-thermal as well as thermal effects contribute to the efficacy of microwave ablation [3]. George et al. reported unfolding of enzymes caused by direct electromagnetic impacts either on protein structure or on hydration-water [33]. Furthermore, Yu and Yao reported an inhibition of DNA synthesis and proliferation arrest in rabbit lens cells, which led to apoptotic changes. Reduced intercellular communication through gap junctions as well as repairable induced DNA damage were also reported, both resulting in an altered cellular stress response [34]. An important finding was that the development of cataracts is not a stochastic but a deterministic effect that correlates with the power and duration of exposure. The energy-efficacy curve in our study ( $\bullet$ Fig. 2 ) cuts the $x$-axis at a value greater than zero, which indicates that there is a minimum energy required to have an effect. This threshold energy is typical of the transition from stochastic to deterministic effects, as in radiation therapy, for example. The intention of the study was to establish an energy-efficacy calibration curve in order to better estimate the energy needed per volume of ablation. Similar calibration has been established for radioiodine therapy. There is currently no comparable correlation between the transmitted energy and volume-of-interest in public research concerning thyroid nodules treated by MWA. Certainly, these results and values are not transferable to every patient and should therefore be seen as a reference point, which may improve therapeutic handling of MWA. Additional guidance via ultrasound is indispensable here and should still be the most essential part of guidance during ablation. Nonetheless, the transmitted energy should be taken into account and certainly improves therapeutic handling.

\section{Conclusion}

\section{$\nabla$}

Supplementary to ultrasound guidance and temperature measurements, the method for estimating the required energy per ablative volume provided by this study should help to improve the efficacy of MWA of benign thyroid nodules and to avoid under- or overtreatment.

\section{Affiliations}

1 Department of Nuclear Medicine, Johann Wolfgang Goethe University Hospital, Frankfurt, Germany

2 Radiology, Multiorgan Screening Foundation, Munich, Germany

${ }^{3}$ German Center for Thermoablation of Thyroid Nodules, Johann Wolfgang

Goethe University Hospital, Frankfurt a. Main, Germany

4 Department of General and Visceral Surgery, Agaplesion Elisabethenstift Darmstadt, Germany

${ }^{5}$ Department of Diagnostic and Interventional Radiology, Johann Wolfgang Goethe University Hospital, Frankfurt, Germany

\section{Literature}

1 Bernardi S, Dobrinja C, Fabris B et al. Radiofrequency Ablation Compared to Surgery for the Treatment of Benign Thyroid Nodules. Int J Endocrinol 2014; 2014: 1-10

2 Papini E, Rago T, Gambelunghe $G$ et al. Long-term efficacy of ultrasound-guided laser ablation for benign solid thyroid nodules. Results of a three-year multicenter prospective randomized trial. J Cli Endocrinol Metab 2014; 99: 3653-3659

3 Korkusuz H, Nimsdorf F, Happel C et al. Percutaneous microwave ablation of benign thyroid nodules. Functional imaging in comparison to nodular volume reduction at a 3-month follow-up. Nuklearmedizin 2014; 54: 13-19

4 Lombardi CP, Raffaelli M, Princi P et al. Video-assisted Thyroidectomy: Report on the Experience of a Single Center in More than Four Hundred Cases. World J Surg 2006; 30: 794-800

5 Zhang $P$, Zhang HW, Han XD et al. Meta-analysis of comparison between minimally invasive video-assisted thyroidectomy and conven- tional thyroidectomy. Eur Rev Med Pharmacol Sci 2015; 19: 1381 1387

6 Puntambekar SP, Palep RJ, Patil AM et al. Endoscopic thyroidectomy: Our technique. J Minim Access Surg 2007; 3: 91 -97

7 Ahmed M, Brace CL, Lee FT et al. Principles of and advances in percutaneous ablation. Radiology 2011; 258: 351-369

8 Brace CL. Microwave tissue ablation: biophysics, technology, and applications. Crit Rev Biomed Eng 2010; 38: $65-78$

9 Yue $W$, Wang $S$, Wang $B$ et al. Ultrasound guided percutaneous microwave ablation of benign thyroid nodules: Safety and imaging followup in 222 patients. Eur J Radiol 2013; 82: e11 - e16

10 Korkusuz H, Happel C, Heck K et al. Percutaneous thermal microwave ablation of thyroid nodules. Nuklearmedizin 2014; 53: $123-130$

11 Shin JH, Baek JH, Ha EJ et al. Radiofrequency ablation of thyroid nodules: Basic principles and clinical application. Int J Endocrinol 2012; 2012: 7

12 Saggiorato E, Angusti T, Rosas R et al. 99mTc-MIBI Imaging in the presurgical characterization of thyroid follicular neoplasms: relationship to multidrug resistance protein expression. J Nucl Med 2009; 50: 17851793

13 Theissen P, Schmidt M, Ivanova T et al. MIBI scintigraphy in hypofunctioning thyroid nodules-can it predict the dignity of the lesion? Nuklearmedizin 2009; 48: 144-152

14 Feng B, Liang $P$, Cheng $Z$ et al. Ultrasound-guided percutaneous microwave ablation of benign thyroid nodules: experimental and clinical studies. Eur J Endocrinol 2012; 166: 1031 - 1037

15 MonchikJM, Donatini G, Iannuccilli J et al. Radiofrequency Ablation and Percutaneous Ethanol Injection Treatment for Recurrent Local and Distant Well-Differentiated Thyroid Carcinoma. Ann Surg 2006; 244: 296-304

$16 \mathrm{Yu}$ J, Liang $P, Y u$ X et al. A comparison of microwave ablation and bipolar radiofrequency ablation both with an internally cooled probe: Results in ex vivo and in vivo porcine livers. Eur J Radiol 2011; 79: $124-130$

17 Fan W, Li X, Zhang L et al. Comparison of microwave ablation and multipolar radiofrequency ablation in vivo using two internally cooled probes. Am J Roentgenol 2012; 198: W46-W50

18 Baek JH, Lee JH, Valcavi R et al. Thermal ablation for benign thyroid nodules: radiofrequency and laser. Korean J Radiol 2011; 12: 525-540

19 Cosgrove D, Piscaglia F, Bamber J et al. EFSUMB Guidelines and Recommendations on the Clinical Use of Ultrasound Elastography. Part 2: Clinical Applications. Ultraschall in Med 2013; 34: 238-253

20 Korkusuz Y, Erbelding C, Kohlhase K et al. Bipolar Radiofrequency Ablation of Benign Symptomatic Thyroid Nodules: Initial experience with Bipolar Radiofrequency. Fortschr Röntgenstr 2016; 188: 671 -675

21 Piscaglia F, Nolsøe C, Dietrich CF et al. The EFSUMB Guidelines and Recommendations on the Clinical Practice of Contrast Enhanced Ultrasound (CEUS): Update 2011 on non-hepatic applications. Ultraschall Der Medizin - Eur J Ultrasound 2012; 33: 33-59

22 Claudon AM, Dietrich CF, Choi BI et al. Guidelines and Good Clinical Practice Recommendations for Contrast Enhanced Ultrasound (CEUS) in the Liver - Update 2012. Ultraschall Der Medizin - Eur J Ultrasound 2012; 34: $11-29$

23 Schleder S, Janke M, Agha A et al. Preoperative differentiation of thyroid adenomas and thyroid carcinomas using high resolution contrast-enhanced ultrasound (CEUS). Clin Hemorheol Microcirc 2015; 61: 13-22

24 Wiggermann P, Jung EM, Glöckner S et al. Real-time elastography of hepatic thermal lesions in vitro: Histopathological correlation. Ultraschall Der Medizin 2012; 33: 170-174

25 Wiggermann P, Brünn K, Rennert J et al. Monitoring during hepatic radiofrequency ablation (RFA): Comparison of real-time ultrasound elastography (RTE) and contrast-enhanced ultrasound (CEUS): First clinical results of 25 patients. Ultraschall Der Medizin 2013; 34: 590-594

26 Mauri G, Cova L, Tondolo T et al. Percutaneous Laser Ablation of Metastatic Lymph Nodes in the Neck From Papillary Thyroid Carcinoma: Preliminary Results. J Clin Endocrinol Metab 2013; 98: E1203-E1207

27 Chiang J, Hynes K, Brace CL. Flow-dependent vascular heat transfer during microwave thermal ablation. Conf Proc IEEE Eng Med Biol Soc 2012; 2012: $5582-5585$

28 Bhardwaj N, Dormer J, Ahmad F et al. Microwave ablation of the liver: a description of lesion evolution over time and an investigation of the heat sink effect. Pathology 2011; 43: 725-731

29 Lubner MG, Brace CL, Ziemlewicz TJ et al. Microwave ablation of hepatic malignancy. Semin Intervent Radiol 2013; 30: 56-66 
30 Wright AS, Sampson LA, Warner TF et al. Radiofrequency versus microwave ablation in a hepatic porcine model. Radiology 2005; 236: $132-$ 139

31 Lu Y, Nan Q Du J et al. Experimental study on thermal field in the vicinity of arterial bifurcation in microwave ablation therapy. Int J Hyperthermia 2010; 26: 316-326

32 Sun $Y$, Wang $Y$, Ni X et al. Comparison of Ablation Zone Between 915and 2,450-MHz Cooled-Shaft Microwave Antenna: Results in In Vivo Porcine Livers. Am J Roentgenol 2009; 192: 511 -514
33 George DF, Bilek MM, McKenzie DR. Non-thermal effects in the microwave induced unfolding of proteins observed by chaperone binding. Bioelectromagnetics 2008; 29: 324-330

$34 \mathrm{Yu}$ Y, Yao K. Non-thermal Cellular Effects of Low-power Microwave Radiation on the Lens and Lens Epithelial Cells. J Int Med Res 2010; 38: $729-736$ 